\title{
Hamvas, Béla. 2016. The Philosophy of Wine (trans. Peter Sherwood). Budapest: Medio Kiadó. 115 pp.
}

\author{
Reviewed by Cain Todd", Lancaster University
}

There can be no getting around the fact that the newly translated The Philosophy of Wine, written by Béla Hamvas (1897-1968), a prolific Hungarian essayist, novelist and translator with a wide range of cultural interests, who was accepted in Hungary (at least among some scholars) as a modern metaphysical thinker, and whose work has been eliciting scholarly interest in part because under communism it was banned and mostly published only after 1989, is a very strange and idiosyncratic book. It is a "philosophical" work only in the loosest sense of that word and does not resemble in any way the work currently being pursued by professional philosophers, like this reviewer, writing on the burgeoning topic of wine. Hamvas's Philosophy does have, perhaps, some fleeting similarities with Roger Scruton's I Drink Therefore I Am - A

Philosopher's Guide to Wine (London and New York: Bloomsberry Publishing, 2010), as both books offer a rambling stroll through a myriad of curious and subjective reflections on the appreciation of wine, and both seek to somehow tie this appreciation to the ideas and values of a vaguely Christian (but in parts also quasi-Pagan) spirituality. In Hamvas's case, however, the religious discussion seems to be simultaneously tongue-in-cheek and quite serious as he casts his book as a work that is both for and against atheism, so that it is difficult to decide if atheist wine lovers would find this contradictory stance an irritating or an amusing conceit. In any case, one has trouble imagining any of them converting after reading this work, which is more of a testament to the author's vigorous love of wine than to his capacity for philosophical or religious argumentation.

How is the appreciation of wine relevant to the truth or falsity of atheism? A good question and one that is, at best, only very obliquely answered in this book, whose central tenet seems to be that atheism is incompatible with the deep love for the spiritual intoxication that wine can give. Ignoring the obvious falsity of this claim, one can perhaps attain some sense of the author's style by looking at the three parts into which the book is divided.

In the first part, Hamvas offers us what he calls a "Metaphysics" of wine that is only very tenuously metaphysical. He proceeds to situate wine in a kind of a tripartite hierarchy, according to which there are three hot fluids (water, oil, and wine) and three cold ones (tea/coffee, beer, and milk) with each liquid having "intellectual" correspondences with systems such as the planets, the days of the week, the musical scale and so on. So far, so pagan, and so obscure.

*c.todd@lancaster.ac.uk

$($ (c) $)$ EY

ULIS D-Sont
New articles in this journal are licensed under a Creative Commons Attribution 4.0 International License.

This journal is published by the University Library System of the University of Pittsburgh as part of its D-Scribe Digital Publishing Program and is cosponsored by the University of Pittsburgh Press 
Hamvas's primary concern here seems to be to express the idea that wine is what he calls a "hieratic mask," namely, that it brings relief from evil, although he does not clarify how and from what sort of evil. What he does say is that wines are somehow like women in how we (meaning men) experience or so-to-speak "taste" them, and here he extemporises on this theme by noting the parts of a woman he most likes and why - e.g. "These tiny little dimples in the inside bend of the knee give off an incomparable fragrance of warm oils" (41) - and by stating that Pietists and Puritans should abandon the path of abstraction and themselves take matters more seriously by studying women (and presumably wine) in detail. Thus, he concludes that like women, each wine is individual and distinctive:

In every wine...there lives a genie of its own that cannot be replicated or imitated. This genie is the oil's materialised form. Its mask. Each part of the woman's body has its characteristic scent, which cannot be confused with any other. How can this be? Because each is inhabited by a different little daemon. Wine is a beverage with a spiritual oilcontent. In each wine there lives a little angel who, when a person drinks it, does not die but makes its way among the innumerable little fairies ad angels who inhabit that person (42).

Did Hamvas himself believe in this "taxonomy"? Did he mean it to be taken seriously or merely metaphorically? Is it supposed to be funny? It hardly matters, since the book continues throughout in this inimitable, puzzling, and entirely non-informative style, leaving the reader with a clear sense that Hamvas did not write his wine philosophy with any distinct readership in mind and that presumably he was indifferent to whether anyone could actually learn anything about wine by reading his book. Hamvas then finishes this first part on "metaphysics" with some bombastic and barely comprehensible observations about the authentic superiority of Christianity over atheism.

After drawing some more pagan-like parallels or connections among wine, stones, oils, and women, as well as among lunar wines, polyphonic wines, and brunettes versus blondes (this time referring to wines, not women), in the second part of the book the author deals with more interesting issues, including some actual empirical observations about various Hungarian wines and regions. Here Hamvas makes mildly interesting distinctions between wines of the plains and wines of the hills, interspersing his observations with asides concerning the nature of wine as love in liquid form, noting that wine - like women - is a complete world unto itself, and that some grapes taste awful but make decent wine. It is perhaps all too easy to criticize the idiosyncrasy and hardly disguised misogyny of such discernments, yet one cannot but marvel at Hamvas's vital, sensual and synesthetic employment of various senses and sensibilities; and in this respect, one must acknowledge the book's marvellously vivid and vivacious translation by Peter Sherwood.

The third and final part of the book offers the reader a lengthy and detailed account of what to eat with certain wines, and how and when to drink these wines. This part offers what I take to be a humorous diatribe about the correct size of wine glasses - for which according to Hamvas atheists have no feeling - as well as the sage advice never to hide away when drinking, since "If you hide away, you will be like the thighs of that woman who did not remove her shift even on her wedding night. You will become devious, purblind, and mawkish" (92). There follow some more profound thoughts about wine and women: "Wine contains all the oils of 
noble and ignoble whorishness, incandescently red and white-hot, and when a woman drinks wine, it becomes clear which way she inclines" (98). Then comes, as in the closing section of the first part, a final rant against atheism.

As should be relatively clear from this review, Béla Hamvas's Philosophy of Wine is not easy to assess. It is not very informative, although it does mention an impressive array of Hungarian wines and grape varieties of which even many Hungarians may be unaware, and which will certainly provoke some wine enthusiasts to explore further. It is rambling in structure and style, manifesting an obsession with women and atheists, with a tendency to obscure reflection on the one hand and concrete but quite idiosyncratic observations about food and drink on the other. It is hard to know whether to take this book seriously or not. If taken seriously, there is very little factual knowledge here to be acquired, and yet if taken non-seriously, it is hard to imagine what sort of readers will be amused. Putting aside the anti-communist heroic glamour attached for decades to Hamvas's work and memory, it would be tempting to conclude that this puzzling little book is almost entirely pointless, and yet some may find here a peculiar charm, as well as some insight into a long-past sensual world that has been lovingly re-captured by Sherwood's eloquent translation. 